\title{
CHINESE POLITICS IN THE 2016 SARAWAK STATE ELECTIONS: CASE STUDIES OF DUDONG AND BAWANG ASSAN SEATS
}

\section{Helen Ting Mu Hung}

Institute of Malaysian and International Studies, Universiti Kebangsaan Malaysia, Selangor, MALAYSIA

Email: helenting@ukm.edu.my

Published online: 29 October 2021

To cite this article: Ting, Helen Mu Hung. 2021. Chinese politics in the 2016 Sarawak state elections: Case studies of Dudong and Bawang Assan seats. Kajian Malaysia 39(2): 71-94. https://doi.org/10.21315/km2021.39.2.4

To link to this article: https://doi.org/10.21315/km2021.39.2.4

\begin{abstract}
This article examines local Chinese electoral politics in Sarawak during the 2016 Sarawak state elections based on a case study of two Chinese-majority marginal seats in Sibu district, namely Dudong and Bawang Assan. It examines the discourse and strategies deployed by the ruling Barisan Nasional (BN) and the opposition Democratic Action Party (DAP) and other independent candidates in the two constituencies. Candidates of the former in both seats were prominent leaders who had left the Sarawak United People's Party (SUPP) - a major BN component party - to form a rival splinter party called the United People's Party (UPP) and had contested as "BN direct candidates." The article provides insights into how the intricate political dynamics on the ground shaped the electoral outcomes. Analysis of the voting patterns in polling districts provides a more nuanced understanding of the purported "increase" in Chinese support, revealing an urban-rural contrast. Both DAP candidates retained majority support in urban Chinese areas, albeit with reduced vote shares and absolute numbers due to abstention. Rural Chinese voters, on the other hand, manifested a clear surge in their support for BN, both in absolute numbers and vote share, contributing decisively to the victories of the two BN direct candidates. The findings are based on field observation, in-depth interviews with party leaders and informants, as well as analysis of polling district results of the two constituencies.
\end{abstract}

Keywords: "Adenan effect", Sarawak Chinese voters, urban-rural divide, SUPPUPP conflicts, DAP 


\section{INTRODUCTION}

The resounding victory of the ruling Barisan Nasional (BN) in the 2016 Sarawak state election was largely attributed to the success of the populist reformist agenda launched by Chief Minister Adenan Satem after he assumed office in March 2014. His predecessor, Taib Mahmud, had ensured that Sarawak remained the "fixed deposit" in securing the national electoral mandate of BN during his long reign, only to see a continual slide of support among the more informed urban Chinese electorate from the 2006 state election onwards. In the face of multiplying allegations of corruption, nepotism and abuse of power against him, Taib cuts a particularly unpopular figure among them (Faisal 2011; Chin 2015). Nonetheless, as the share of Chinese-majority state seats in Sarawak have been maintained at around a fifth of the total seats, $\mathrm{BN}$ has continued to maintain a firm grip on the state government.

In view of the popularity of Adenan Satem and the 2015 re-delineation exercise of the state electoral constituencies, which was predicted to further favour BN, $\mathrm{BN}$ was expected to win easily in the 2016 state election. The main question was the extent to which and whether this feel-good effect created by Adenan could be translated into more Chinese-majority seats for BN. The symbolic importance of winning back at least a few more Chinese-majority seats as an endorsement of Adenan's policy was not lost.

There were 16 Chinese-majority seats out of the total of 82 state seats in the 2016 state election. Some of the closely watched Chinese-majority seats were those marginal seats with less than $10 \%$ of victory margin in 2011 , which may have changed hands easily with a slight vote swing. They included seats such as Batu Kawah (51.9\%), Dudong (50.4\%) and Senadin (50.2\%), which were won with a bare majority, as well as Bawang Assan (57.0\%) and Piasau (57.6\%). However, the swing exceeded expectations as Democratic Action Party (DAP) not only lost the three marginal seats but also two other seats previously won with $60 \%$ to $62 \%$ of vote shares (see Table 1). DAP was only able to retain seven seats with a reduced majority.

The Sarawak United People's Party (SUPP), the Chinese-based BN component party, managed to increase its Chinese majority seats from two to six, including the new seat of Batu Kitang with $53.5 \%$ of voters' support, in which it defeated both the candidates of the opposition parties of Parti Keadilan Rakyat (PKR) and DAP as well as two other independent candidates. Despite gaining back four seats from DAP and winning a newly delineated seat, SUPP nonetheless lost their prerogative to contest in four other Chinese-majority seats to its splinter party, 
the United People's Party (UPP) (as will be explained in the next section). This impact was most keenly felt in the Sibu district, where three of the four seats traditionally allocated to SUPP were assigned to UPP candidates, inclusive of the two case studies undertaken in this article.

Table 1: Results of Chinese-majority seats in 2011 and 2016 state elections

\begin{tabular}{|c|c|c|c|c|c|c|}
\hline \multirow[b]{2}{*}{ Name of seat } & \multicolumn{3}{|c|}{2011} & \multicolumn{3}{|c|}{2016} \\
\hline & $\begin{array}{l}\text { Winning } \\
\text { party }\end{array}$ & $\begin{array}{c}\text { Majority } \\
\text { vote }\end{array}$ & $\begin{array}{c}\text { Vote share } \\
(\%)\end{array}$ & $\begin{array}{l}\text { Winning } \\
\text { party }\end{array}$ & $\begin{array}{c}\text { Majority } \\
\text { vote }\end{array}$ & $\begin{array}{c}\text { Vote share } \\
(\%)\end{array}$ \\
\hline Piasau (N.73) & DAP & 1,590 & 57.6 & SUPP & 2,112 & 57.8 \\
\hline Pujut (N.74) & DAP & 3,849 & 63.4 & DAP & 1,759 & 52.6 \\
\hline Senadin (N.75) & SUPP & 58 & 50.2 & SUPP & 3,538 & 58.8 \\
\hline Tanjung Batu (N.68)* & DAP & 6,930 & 69.2 & DAP & 2,548 & 59.1 \\
\hline Bukit Assek (N.51) & DAP & 8,827 & 73.5 & DAP & 4,497 & 61.1 \\
\hline Pelawan (N.54) & DAP & 6,391 & 65.8 & DAP & 4,314 & 58.3 \\
\hline Bawang Assan (N.53) & SUPP & 1,808 & 57.0 & UPP & 4,131 & 61.6 \\
\hline Dudong (N.52) & DAP & 317 & 50.4 & UPP & 2,146 & 46.4 \\
\hline Repok (N.45) & DAP & 2,679 & 60.2 & SUPP & 943 & 52.0 \\
\hline Meradong (N.46) & DAP & 2,687 & 62.1 & SUPP & 1,516 & 56.2 \\
\hline Batu Lintang (N.11) & PKR & 8,381 & 72.0 & PKR & 4,385 & 61.6 \\
\hline Batu Kawah (N.14) & DAP & 543 & 51.9 & SUPP & 2,085 & 54.1 \\
\hline Kota Sentosa (N.12) & DAP & 4,824 & 61.8 & DAP & 2,819 & 58.2 \\
\hline Pending (N.10) & DAP & 7,595 & 68.0 & DAP & 5,012 & 62.6 \\
\hline Padungan (N.9) & DAP & 7,884 & 72.6 & DAP & 4,270 & 64.3 \\
\hline Batu Kitang (N.13) & - & - & - & SUPP & 1,840 & 53.5 \\
\hline
\end{tabular}

Note: * Named "Kidurong" in 2011 state election.

This article examines local Chinese electoral politics in Sarawak based on case studies of two Chinese-majority marginal seats, namely, Dudong and Bawang Assan. It explores how the "Adenan effect" played out during the campaign by examining the discourse and strategies deployed by BN and the opposition in the two constituencies in Sibu district. Their geographical proximity facilitated fieldwork being conducted concurrently. The other two Chinese-majority seats in the district, Pelawan and Bukit Assek, consist of around $90 \%$ Chinese voters and were both won by DAP in 2011 with more than $65 \%$ of vote share. They were hence regarded as safe seats for DAP and in fact both were retained with a comfortable majority. 
Methods used to collect information for this study during fieldwork included a survey of local newspapers, observation of campaign activities, inspection of campaign posters, materials and sites, in-depth interviews with more than two dozen party leaders and informants from SUPP, DAP, UPP and independent candidates of both constituencies, as well as securing polling district results of the two constituencies through party leaders.

The article consists of three main sections. The first section elaborates on two aspects of the historical and political context, which are important in situating the two selected constituencies within the overall political dynamics during the 2016 state election. In the first instance, it provides an overview of the changing landscape of Chinese politics in Sarawak. Next, it analyses how Adenan skilfully pre-empted contentious current and legacy issues to carve out an inclusive reformist image for himself during the two-year duration of his chiefministership, creating what was known popularly as the "Adenan feel-good effect" in anticipation of the state election.

The second section delves into the two case studies which are presented in three parts. It begins by providing background information on the constituencies and candidates. This is followed by a synthesis of how the contending parties positioned themselves on several issues articulated in the campaign discourses. The final part of the section analyses the voting patterns by polling district when compared with those of the 2011 elections in the two constituencies. The last section concludes by highlighting the salient findings of the study.

\section{HISTORICAL AND POLITICAL CONTEXT}

\section{Shifting Dynamics of Chinese Politics in Sarawak}

Historically, Chinese politics in Sarawak has been inseparable from the SUPP. Since the formation of Malaysia, despite radical changes in its political orientation over the decades, the SUPP has largely enjoyed the support of the Chinese voters in Sarawak. On the other hand, as an avowedly multi-ethnic party, its political appeal among the Dayak has been on a steady decline (Chin 2012). What is remarkable about SUPP, as noted by Chin (1997), is that through the various phases of Sarawak politics and despite its "near total turnabout" from a left-leaning, anti-Federation party into an "establishment party" (p. 281) as a member of the governing BN, it has been able to retain the electoral support of its Chinese constituencies. That said, the new millennium has witnessed important changes to the landscape of Chinese politics in Sarawak. 
In the 2006 and 2011 Sarawak state elections, DAP which has been SUPP's main rival, achieved a significant breakthrough in the Chinese-majority constituencies. In the 2006 state elections, BN lost nine seats of which seven were Chinese-majority seats, with the DAP gaining six of these and another by PKR (Faisal 2011). BN's electoral losses increased to 16 seats in 2011, with DAP doubling up its gain and PKR increasing its representation to three, while one seat went to an independent. All 12 seats won by DAP were Chinese-majority seats while PKR took one of them. In effect, SUPP could only retain two out of the 15 Chinese-majority seats. Chinese voters' support for BN sank from $40 \%$ in 2006 to $24.6 \%$ in 2011 . One analyst estimated that Sarawak Chinese support went down further to $20 \%$ in the 2013 general election (Tan 2016), with DAP winning five Chinese-majority parliamentary seats in Sarawak, a notable jump from only one in 2008. In fact, SUPP lost in all the Chinesemajority parliamentary seats it contested as PKR took the sixth. In other words, DAP has emerged as a formidable rival against SUPP for Chinese votes in Sarawak. Despite this, BN retained its two-thirds majority in the 2011 state election, winning 55 out of the total of 71 seats and so this electoral outcome has greater implications for the political future of SUPP than to the overall performance of Sarawak BN.

Chinese voters in Sarawak used to be known to selectively support DAP for parliamentary contests while ensuring at the same time a strong Chinese voice at the state level through SUPP representation (Chin 1996). For instance, the late Sim Kwang Yang, a three-term Member of Parliament for Bandar Kuching seat, was never successful in winning a state seat within his parliamentary constituency despite his repeated attempts. It was in this light that the 2011 electoral success of the DAP bore an added significance: that the Chinese voters in Sarawak no longer bought into the argument of SUPP to support them for a strong Chinese representation in the Sarawak state government.

The stake of the 2016 state election for the political survival of SUPP was further heightened in view of the establishment of a splinter party, the UPP by former SUPP leaders. In mid-May 2014, conflicts with party president George Chan had led to Wong Soon Koh, who was the deputy secretary-general of SUPP and Bawang Assan state assemblyman, quitting the party together with three other Iban state representatives (one of them was also a state assistant minister) and their supporters. They subsequently formed UPP and lobbied to join BN unsuccessfully due to strong objections from SUPP. In preparation for the 2016 state elections, the allocation of seats for contest among $\mathrm{BN}$ component parties became a thorny issue because Chief Minister Adenan Satem had to accommodate those incumbent lawmakers who had exited their original 
parties to form UPP and Teras, another splinter party, of Sarawak Progressive Democratic Party (SPDP) which found itself in a similar situation to SUPP. Consequently, instead of the 21 seats SUPP aimed for, they were only allocated 13 seats (Bernama 2016). Adenan also allowed candidates from UPP and Teras to contest using the BN electoral symbol as "BN direct candidates." Hence the electoral performance of SUPP against UPP would determine the political survival of both.

\section{The Adenan "Feel-good" Factor}

After taking over the chief-ministership in March 2014, Adenan Satem lost no time in reaching out to all races through a long list of popular policies. Three months into his office, Adenan signed an integrity pledge in which he committed himself not to award timber concession licences or state land to his family members. He then made all his ministers and assistant ministers do the same and also declare their assets (The Malaysian Insider 2015a). Adenan even publicly praised the media for exposing cases of corruption and illegal logging in Sarawak, which helped to deter such practices.

Notable was the inclusive discourse Adenan espoused, which affirmed the multicultural and multi-religious character of the state. He instituted bilingual official language policy by making the English language an official language of the Sarawak state government alongside Malay. Adenan also openly pledged to reject forced conversions and assured Christians of their right to use the word "Allah". The official website of the Sarawak government also removed a prior reference to Islam as the official religion of the state after the opposition leader Baru Bian questioned its legal basis during one of the state assembly sittings (Tawie 2015). Just before the election was called, Adenan declared that the category "lain-lain" for ethnicity in official forms was henceforth abolished and that this would enable the Dayak and other indigenous ethnic groups to state their respective ethnic affiliation when filling in the forms. He also repeatedly criticised those who called the Chinese pendatang (immigrants), acknowledged the Chinese contribution to Sarawak and affirmed that Malaysia is their home. Since he took office, Adenan has provided allocations every year to Chinese independent schools: RM3 million in 2014, RM4 million in 2015 and RM5 million in 2016 just a month before the state election. He also decided that the state government will recognise the Unified Examination Certificate (UEC), the Chinese independent school qualification equivalent of Sijil Tinggi Persekolahan Malaysia (STPM), thus allowing UEC holders, provided they have a pass in Sijil Pelajaran Malaysia (SPM) Bahasa Malaysia subject, to apply and work in Sarawak's civil service and the state legislature. UEC holders also henceforth 
became eligible to apply for study loans and grants from Yayasan Sarawak to study in any government-recognised institutions of higher learning. They also became eligible to apply to study at Universiti Teknologi Malaysia's Sarawak campus provided they passed the SPM Bahasa Malaysia subject (Malaysiakini 2016a).

Among his most popular policy decisions was the abolition of tolls in Sarawak (Malaysiakini 2016b). As the election campaign was on course, he further announced a graduated reduction in residential assessment rates (Banji 2016) which was a clear attempt at mitigating the unhappiness of urban voters over the rising costs of living.

Adenan's inclusionary discourse as well as his policies towards the Chinese were well received. According to a Universiti Malaysia Sarawak (UNIMAS) opinion poll, Chinese respondents gave him an approval rate of $64 \%$ before the election. On the other hand, this was far below his overall approval rate of $85.5 \%$ in the same poll and fell short of the $74 \%$ endorsement received by the state DAP Chairman, Chong Chieng Jen (Tan 2016). Another poll conducted by Merdeka Centre in January 2016 reported that the Chinese satisfaction rate for Adenan was $71 \%$ while his overall approval rate was $81 \%$. Nonetheless, $56 \%$ of the respondents wanted to see a stronger opposition in the state, even though a high approval rate of $62 \%$ for Chong was reported only among Chinese respondents, while the majority of other ethnic groups were unsure about his performance (Malaysiakini 2016b).

An underlying theme linking many of these issues was the rejection of what are perceived as Malay nationalist and Islam-related supremacist federal policies and domination, which were felt to have impinged on the multicultural way of life in Sarawak and robbed Sarawak of the rightful political and economic benefits it could have enjoyed. Adenan tapped into this widespread sense of alienation against Putrajaya as indicated by his policies on language, Chinese education and religion. From time to time, Adenan had no qualms criticising specific federal policies as "stupid", such as the abolition of the teaching of Mathematics and Science in English programmes. He also pledged to fight for more autonomy from Putrajaya for Sarawak and asked Sarawakian voters to give him a stronger mandate to enable him to do so.

The groundswell of Sarawak regionalist sentiment manifestly reached a peak in 2015, driven by a loosely coordinated, multi-ethnic Sarawak for Sarawakians (S4S) Movement. They had successfully organised a public event named Sarawak Independence Walk in Kuching on 22 July 2015 in which around 3,000 people 
were estimated to have participated to commemorate what they called the "Independence Day" of Sarawak. It marked the anniversary of the day when the British handed over power to the first Sarawak Chief Minister, Stephen Kalong Ningkan, in anticipation of the formation of Malaysia. Demanding for "full autonomy" of Sarawak to be restored in accordance with the 1963 Malaysia Agreement, the movement also kickstarted a signature campaign on Malaysia Day and managed to collect 270,000 signatures by the end of 2015. The petition called on the state government to enact a Referendum Ordinance which would require the state government to hold a referendum on any policy changes on issues affecting Sarawak's rights on religion, immigration, petroleum resources and language.

Adenan cleverly harnessed this wellspring of anti-federal discontentment. The state government even held a parallel commemorative event on 22 July 2015 and declared the day a public holiday. In addition, a bipartisan motion was tabled and passed in the state assembly in December 2015 to give the state government the mandate to negotiate with Putrajaya to realign federal policies on education, health and official language "so that they are consistent with the constitutional safeguards and the terms of the Inter-Governmental Committee Report" (The Malaysian Insider 2015b). As explained, he urged the Sarawak voters to give him a bigger mandate to strengthen his hand in the ongoing process of negotiation on the devolution of power from Putrajaya to Sarawak.

In sum, Adenan appeared to have played all the right cards in tackling the legacy issues he inherited from Taib. He initiated several measures that indicated his concern for people's challenges in addressing the rising costs of living. $\mathrm{He}$ also articulated an inclusive political vision that struck a chord among the multi-ethnic Sarawakian electorate who largely disapproved of the "Malayacentred" Malay nationalist and religious ideology. By doing so, he successfully shaped the political narrative in his favour ahead of the election and placed the opposition on the defensive.

\section{CASE STUDIES OF DUDONG AND BAWANG ASSAN SEATS}

As mentioned, the dynamics of Chinese politics in Sibu district was notably affected by the fact that Adenan decided to allocate three out of the four Chinesemajority seats to UPP candidates. These included the Dudong and Bawang Assan seats. The local electoral campaign discourses and strategies were calibrated accordingly. The BN candidates, as will be shown below, capitalised fully on the popularity of Adenan in their campaign materials and slogans. Before going 
into the substance of the campaign, a detour to provide the needed background information of the two constituencies is in order.

Dudong and Bawang Assan respectively form part of the parliamentary seats of Lanang and Sibu. Both constituencies encompass urban and rural populations, and have a similar ethnic composition, with $54.2 \%$ Chinese, $36.8 \%$ Iban and 7.7\% Malay/Melanau voters in Dudong; and 55.1\% Chinese, $38.8 \%$ Iban and $5.3 \%$ Malay/Melanau voters in Bawang Assan. On the other hand, Dudong has around 29,000 voters, a third more than that of the fewer than 18,000 voters in the less accessible Bawang Assan.

Sibu district used to be a political stronghold of the SUPP. From the time of Malaysia's formation in 1963 until 1996, all of its state assembly representatives were from SUPP. Then DAP won the seats of Bukit Assek and Pelawan for a single term. They were then wrested back by SUPP in 2001. The late Wong Ho Leng of DAP managed to regain the state seat of Bukit Assek in 2006 and to retain it in 2011 as well. In the 2011 state election, DAP also succeeded in capturing Pelawan and Dudong as well as Bukit Assek.

At the level of parliamentary representation in Sibu, SUPP had maintained its dominance from the beginning except for the 1982 general election, whereby it lost the seat of Bandar Sibu to Ling Sie Ming of DAP, and also in 1990 when it lost the same seat (renamed Lanang after delineation exercise) to Jason Wong Sing Nang of DAP. Between 1990 and 2010, Robert Lau Hoi Chew of SUPP was the elected Member of Parliament for Sibu (renamed in 1990 from its original name of Rajang) until his untimely death. Following his passing, a Sibu parliamentary by-election was held on 16 May 2010 in which Wong Ho Leng (DAP) defeated Robert Lau Hui Yew of SUPP. In the general elections of 2013, SUPP lost both the Lanang and Sibu parliamentary seats to DAP for the first time in history (Ngu 2014).

The notable performance of DAP in Sibu district during the 2011 state election and 2013 general election reflected a state-wide trend among DAP candidates in Chinese-majority seats, whereby altogether 12 state seats and five parliamentary seats were captured respectively. In 2016 again, their results mirrored a statewide pattern.

\section{Candidates Contesting in Dudong Constituency (N.52)}

Dudong was a stronghold of SUPP before 2011. Dr. Soon Choon Teck of SUPP was a four-term assemblyman of Dudong (1991-2011) but he was not 
re-nominated to contest in the 2011 state elections. Instead, Wong Soon Koh, the Sibu SUPP branch leader, named his trusted ally, Tiong Thai King as the candidate. Soon collided with Wong over the setting up of a new branch in Dudong and aligned himself with the party president's faction (Chin 2012). As will be explained, this old animosity affected how the Dudong SUPP leadership under Soon positioned themselves against Tiong in the electoral contests for the Dudong seat. In the 2011 state elections, Tiong lost by a slim majority of 317 votes to Yap Hoi Liong of DAP (9,649 versus 9,332). Yap, 45, is a lawyer by profession, and used to be the special assistant to the late Wong Ho Leng when the latter was the Sarawak DAP chairman. Yap also held the position of assistant secretary in the Sarawak DAP Committee.

Even though Tiong Thai King contested the Dudong state seat for the first time in 2011, he is a well-known local figure and had been a four-term Member of Parliament of Lanang (which consists of Dudong and Bukit Assek state seats) between 1995 and 2013. He was defeated in the 2013 general election by Alice Lau Kiong Yieng of DAP (majority 8,630 votes). Tiong had been the chairman of Sibu municipal council from 2004 until June 2019. He is also the executive director of Rimbunan Hijau Group, one of the top six timber companies and business conglomerates in Sarawak.

In the 2016 state election, five candidates were nominated to contest in Dudong, including the incumbent Yap. Tiong, aged 71, was now affiliated to UPP instead of SUPP. Since UPP was not admitted to BN, he was required to formally resign from UPP as a condition to gain nomination as a "BN Direct Candidate" to contest. Mary Ting Yiik Hong, a businesswoman, was contesting under the party flag of State Reform Party (STAR). Two others contested as independents, namely Dr. Benny Lee Chung Fatt and Casper Kayong Umping.

A holder of a master's degree in business administration, Ting, 49, worked as a pharmaceutical manager and had a three years' stint teaching English and Business at United College. She told the press that her mission as a STAR candidate for Dudong was to create awareness among Sarawakians on "the truth about Sarawak" (Boon 2016).

Lee, 49, who is the CEO of College ITA in Sibu joined SUPP after the SUPPUPP split and had been groomed by SUPP to contest in Dudong. He had worked tirelessly among the houses for over a year and built strong rapport with house residents. He claimed to have developed a strong sense of mission for the Dudong constituency (See Hua Daily News 2016). He was the deputy chairman of the SUPP Dudong branch and was proposed to Adenan Satem by SUPP 
to be the $\mathrm{BN}$ candidate. But the seat was instead assigned by Adenan to Tiong from UPP. Lee subsequently quit SUPP to contest as an independent.

Casper Kayong, 64, was formerly a Radio Televisyen Malaysia (RTM) broadcaster. When interviewed by journalists, Casper expressed hope that he could win back Dudong seat with the support of Iban voters so that he could return it to $\mathrm{BN}$,

The Iban voters need Iban YB (people's representatives) in Sibu, because
their population here is more or less the same as that of the Chinese.
It seems that the Ibans have not had an Iban YB over the past 40 years-
the last being Jawan Empaling...If we could only capture Dudong and
surrender it to BN-that would be their wish. (Borneo Post Online 2016)

He also explained that he chose a chair as his electoral symbol because everybody hoped to have his own chair to sit on, and that he believed "nobody wants to sit on the floor" (United Daily News 2016; Utusan Borneo Online 2016). The constituency was a Dayak-majority seat before the delineation exercise conducted in 1985 to 1986 and had elected Iban state representatives before Dr. Soon Choon Teck (Chin 1997, 220, 241).

\section{Candidates Contesting in Bawang Assan Constituency (N.53)}

The contest in Bawang Assan was also a five-corner fight. The incumbent in Bawang Assan seat was Wong Soon Koh, aged 74, a heavy-weight, fourterm assembly man. He beat Alice Lau of DAP in the 2011 state election with a majority of 1,808 votes. Abiding by the condition to contest as a BN direct candidate, he had to resign as the president of UPP in order to do so. It went without saying that it was a mere formality as UPP constituted the backbone in organising his electoral campaign. After the election, UPP declared that they rejected all the resignations submitted by their leaders who contested as BN direct candidates. Wong was the Sarawak Second Minister of Finance and the Minister of Local Government and Community Development in the state government. After the 2016 state election, he was reappointed as the Second Finance Minister and as the International Trade and E-commerce Minister until he resigned in August 2019.

DAP had nominated a fresh face, Stanley Chiew Sung Ngie as its candidate for Bawang Assan. Aged 38, Chiew described himself as a self-employed entrepreneur, and was then pursuing Bachelor of Jurisprudence as an external student of Universiti Malaya. He joined DAP in 2009 as a life member. 
He headed the Sibu DAP youth wing between 2011 and 2013. He is currently the DAP Lanang Branch secretary from 2012 and the organising secretary of the state-level youth wing from 2013. His electoral slogan was, "Ubah (change), for a better future". A third candidate, Adam Wong Sing Wei, aged 40, was a Vice-President of STAR, while the remaining two, Yeu Bang Keng and Watson Bangau Jonathan Renang were contesting as independents.

Yeu Bang Keng, a petty trader aged 48, popularly known as Beng Kor (his Facebook nickname), became well known as an activist for the cause of S4S, administering the Facebook page Sarawak Keluar Malaysia 2021 (Sarawak Exits Malaysia 2021). He was charged under the Communications and Multimedia Act 1998 with refusing to provide his Facebook username and password to the police, who were investigating a comment posted on his Facebook account. S4S supporters collected money to post bail for him and provided him with defence lawyers (Borneo Post 2015a). Yeu was scheduled to appear in the magistrate court one day before the election day but the trial was postponed (Cheng 2016). He was acquitted of the charges on 15 January 2018 (Chua 2018). He claimed to have the support of S4S members to stand for the election (Borneo Post 2016), even though the leading spokesperson of S4S Movement, Peter John Jaban, had previously announced that the movement would not formally endorse any S4S members contesting in the elections (Borneo Post 2015b).

The candidature of Watson Bangau Jonathan, aged 59, was unexpected. Wong Soon Koh expressed surprise at the nomination of Watson as he is a member of the Supreme Council of the Pesaka wing of Pesaka Bumiputera Bersatu (PBB), the dominant component party of Sarawak BN, and was the former branch chairman of PBB and political secretary to the Chief Minister. He was wellknown in Bawang Assan as his father used to be the headman of his longhouse (Borneo Post 2016). Conversations at Bangau's house revealed that there was a lot of discontent with Wong's Iban assistants who acted as his intermediary with the longhouse residents. There were also allegations that some of the allocations for the latter did not reach them as they ended up benefiting those go-betweens. The ringleader also reportedly acted in a rash and arrogant way towards longhouse headsmen, which the researcher witnessed at his campaign visit to a house. Since Bangau had no real prospect of being elected, one informant also wondered whether he had been funded by Wong's enemy to pull away a portion of Iban votes from Wong. 


\section{Campaign Discourse and Issues}

\section{The "Adenan Team"}

In view of the immense popularity of the chief minister, the strategy of the three $\mathrm{BN}$ direct candidates from the UPP in Sibu was to identify themselves as part of the "Adenan Team." They had a standard format of vertical banners (with the respective candidate's photo, name and constituency contested), which urged the voters to "give the Adenan Team a chance" (see Figure 1 for the cover of BN manifesto pamphlet which uses the same slogan). Other banners made references to some of his popular policies. One urged voters to support Adenan for a harmonious society and religious freedom. One banner of Wong Soon Koh read, "Rakyat diutamakan, tol dimansuhkan" (Prioritise the people, abolish the toll) in reference to the recent toll abolition by Adenan. They all used the same BN campaign pamphlets which detailed the various policies implemented by Adenan thus far. BN's electoral manifesto basically promised a continuation of Adenan's policy orientation, including the promise to continue negotiating for an increase in Sarawak's share of oil royalties up to 20\% (BN electoral manifesto pamphlet).

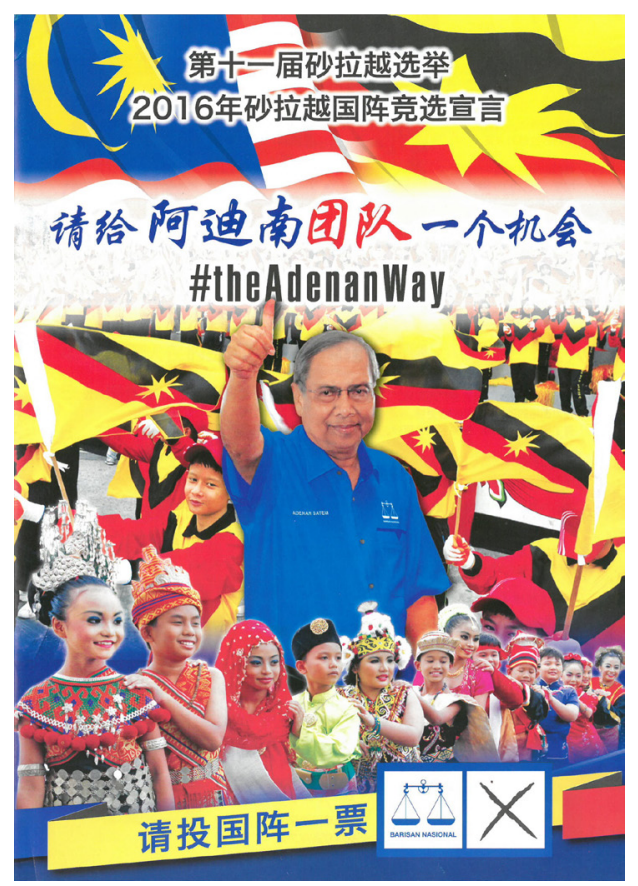

Figure 1: Cover page of BN electoral manifesto with the slogan, "Please give the Adenan Team a chance". 
Individual $\mathrm{BN}$ candidates, who held nightly events, remarked on the notable increase in the size of the crowd when compared with the previous elections. The attendance could still not match the main night rallies organised by DAP, which pooled together all its four candidates for the Sibu district. Ironically, even though the three UPP candidates in Sibu claimed that they were part of the "Adenan Team", they did not hold a single joint rally throughout the campaign.

\section{Reclaim of rights and autonomy for Sarawak}

The campaign conducted by STAR candidates in particular as well as Yeu hinged mainly on issues related to reclaiming Sarawak's rights. The five STAR candidates for Sibu, just as those four of DAP, held nightly rallies together rather than having separate meet-the-people sessions. Issues raised during the campaign included the meagre $5 \%$ oil royalty received by Sarawak for the petroleum resources, and also the Territorial Sea Act 2012 that henceforth limited the state's territorial waters to only within three nautical miles of the coast, which hampered Sarawak's claim to revenue from petroleum resources against the federal coffer. They also criticised the federal government for not respecting the 18-point-conditions set for the formation of Malaysia which covered issues such as education, official language, and the exclusion of Sarawak from being subjected to the designated role of Islam. In addition, STAR candidates also tried to discredit DAP as a West Malaysia-based party.

DAP candidates, on the other hand, emphasised that the autonomy and rights of Sarawak were lost under BN rule and asked how they could now talk about reclaiming the lost rights without admitting their own fault. DAP also dismissed the concept of autonomy in BN's electoral manifesto as real autonomy for Sarawak would mean that the state government retained half of its state revenue and took full control over its education, transportation and other sectors. One of the DAP banners carried the following rhyme in Mandarin, "Najib didn't want to increase oil royalty (for Sarawak), Adenan didn't dare to object; Adenan wants to increase oil royalty, Najib asks him to go home to sleep."

\section{The SUPP-UPP conflicts}

Conflicts between SUPP and UPP had led to alleged attempts of sabotage against rival candidates by planting independent candidates as vote spoilers (Chie 2016). There were also cases whereby disgruntled individuals groomed by the party decided to stand as independents to challenge such arrangements as in the case of Benny Lee in Dudong. While this SUPP-UPP conflict remained muted during the campaigns conducted by the three $\mathrm{BN}$ direct candidates, it became a key 
theme in the campaign of Lee and the only SUPP candidate in Sibu for the seat of Bukit Assek, Chieng Buong Toon. The political survival of SUPP in Sibu was the main highlight in the banners for both Chieng and Lee, even though they were articulated in different ways. Lee emphasised that he was merely fighting to keep the seat for SUPP, and that he would return to SUPP and be part of the BN government should he win the election. His banner slogan read, "SUPP, rumah saya (my home)." Another big canvas displayed as the background of his stage stated, "Save SUPP, defeat UPP, reject DAP." Lee also appeared to enjoy support from local SPDP leaders whose party was in the same boat as SUPP since leaders of their splinter party, Teras, were also allowed to contest as BN direct candidates elsewhere. He was nonetheless seen as a spoiler by the Dudong SUPP branch leadership, as will be explained.

\section{Tycoon money politics}

A familiar theme advocated by DAP candidates was to reject tycoon money politics as two of the BN direct candidates in Sibu were closely associated with big conglomerates. The incumbent DAP candidate for Dudong, Yap Hoi Liong, stressed that he was just someone from a lowly socioeconomic background fighting against a giant tycoon candidate in the person of Tiong. Another BN direct candidate contesting in Pelawan seat, Janet Lau Ung Hie, was the widow of the late Robert Lau Hoi Chew, formerly the Sibu Member of Parliament. The boss of KTS Group, one of the six top business conglomerates in Sarawak dubbed as the "big six", was the nephew of her late husband.

The mainstay of business of the conglomerates associated with Tiong and Lau were both timber and oil palm cultivation, and they were also longstanding business rivals (Ngu 2014; Liew 2017). Both families owned media publishing companies controlling several local newspapers. The Tiong family controlled Sin Chew Daily, Nanyang Siang Pau, China Press and Guan Ming Daily, whereas the Lau family controlled Oriental Daily, Borneo Post, Utusan Borneo and See Hua Daily News (Liew 2017).

Even though Adenan had initially warned the "big six" against corruption and not to "mess with him," vowing to "put the fear of God into people who are dishonest," (Malaysiakini 2014) he had actually approved five Chinese business tycoons or their family members (Tiong and Lau inclusive) as candidates to contest under the logo of $\mathrm{BN}$. Adenan had also gone around speaking to the employees of these companies to urge them to vote for BN, an act condemned by Yap as "threatening them not to vote for the opposition". David Wong, the DAP candidate for Pelawan seat, also attacked these "big six", and asked why 
big conglomerates should monopolise all the contracts to construct bridges and repair roads. He gave details on how the state government had allocated big tracts of land at vastly undervalued prices to several politically well-connected companies, which instantly reaped huge profits from the land they acquired even without making any improvements to the land.

The anti-tycoon discourse was also used by the SUPP-turned-independent candidate Benny Lee. On the back of the t-shirts worn by his 600 or so supporters escorting him to the nomination centre on the nomination day was the slogan "Eradicate tycoon money politics" (United Daily News 2016). This was clearly directed against Tiong.

\section{Malaysia Development Berhad (1MDB) scandal and Goods and Services $\operatorname{Tax}(G S T)$}

DAP events also capitalised on the 1MDB corruption scandal plaguing former prime minister Dato' Sri Najib Razak. One of the popular speakers on this was Tony Pua, who despite having been refused entry by Sarawak, spoke to the crowd through Skype with his image projected on big screens. From time to time, the video recording of Pua's critical intervention on the 1MDB scandal made in the parliament was also played during the rallies. Criticising how huge sums of money had been abused, Pua and other West Malaysian speakers stressed that a vote for Adenan was in reality a vote for Dato' Sri Najib Razak and that any loss of seats by DAP would also mean fewer checks and balances on the government in the face of a failing system of governance. One DAP banner read, "Team Adenan = Team Najib." Another banner read, "An ordinary prime minister, dare to accept extraordinary donation," and right next to the slogan featured the "2.6 billion" figure. It was a play of words in response to Janet Lau's election slogan describing herself as "an ordinary woman doing extraordinary things." One Chinese-language-banner said, "Najib took billions, Adenan still supports Najib."

The imposition of GST and rising costs of living was another theme played up by the opposition. One speaker described the election as a referendum on GST, arguing that with RM30 billion going into the pocket of the federal government, the people had less money to spend, which would affect businesses adversely. He also asked Sibu voters to support DAP candidates to take a stand to say, "No to tycoon, and Yes to (defending) the little rakyat." One DAP banner which tried to link the 1MDB scandal to GST, read, "Billions (of) DEBT owed by 1MDB, GST PAID by you and me." 
The $\mathrm{BN}$ direct candidates, on the other hand, dismissed the state election as the forum to take a stand on issues such as the 1MDB scandal and GST as they were beyond the control and purview of the state government.

\section{Electoral Results for Bawang Assan}

In the five-cornered contest, Wong obtained 9,015 votes, winning with a much bigger majority of 4,131 votes compared with 2011 . This gave him $61.6 \%$ of popular support. Chiew from DAP came second, polling 4,884 votes (33.4\%), a drop of more than 600 votes when compared with his predecessor Alice Lau's performance in 2011.

Wong made significant gains and won in the rural Chinese area (see Table 2), with an increase of almost 600 votes when compared with 2011. Nonetheless, despite significant increase in the number of rural Iban votes he obtained (1,178 votes more), the $74 \%$ support was less than he received in 2011 , mainly because of the 523 votes $(7.5 \%)$ drawn to Watson Bangau, the PBB local leader who contested as an independent. Wong did not do well in the urban Chinese area in 2011, obtaining only $35.1 \%$ of the votes. This time around, despite a drop in the absolute number of votes he obtained in the urban Chinese area, he actually received $4 \%$ more out of the total votes cast. There was a drop in the turnout rate among urban Chinese, even though more Chinese and Iban voters in the rural areas had turned up to vote. The overall turnout rate of $80.6 \%$ was higher than the $77.2 \%$ in the 2011 contest.

Table 2: Micro-analysis of voting pattern in Bawang Assan constituency*

\begin{tabular}{|c|c|c|c|c|c|c|c|c|}
\hline \multirow{3}{*}{$\begin{array}{l}\text { Candidate } \\
\text { Year } \\
\text { Voters' profile }\end{array}$} & \multicolumn{4}{|c|}{ Wong Soon Koh } & \multirow{2}{*}{\multicolumn{2}{|c|}{$\begin{array}{c}\text { Alice Lau } \\
2011\end{array}$}} & \multirow{2}{*}{\multicolumn{2}{|c|}{$\frac{\text { Stanley Chiew }}{2016}$}} \\
\hline & \multicolumn{2}{|c|}{2011} & \multicolumn{2}{|c|}{2016} & & & & \\
\hline & Votes & $\%$ & Votes & $\%$ & Votes & $\%$ & Votes & $\%$ \\
\hline Rural Iban area & 4,009 & 78.6 & 5,187 & 74.0 & 1,091 & 21.4 & 1,227 & 17.5 \\
\hline Rural Chinese area & 1,956 & 48.7 & 2,550 & 56.2 & 2,059 & 51.3 & 1,912 & 42.2 \\
\hline Urban Chinese area & 1,272 & 35.1 & 1,172 & 39.3 & 2,354 & 64.9 & 1,743 & 58.49 \\
\hline Total votes ${ }^{* *}$ & 7,316 & 57.0 & 9,015 & 61.6 & 5,508 & 43.0 & 4,884 & 33.4 \\
\hline
\end{tabular}

Notes: * Those classified as rural Iban areas include the polling districts of Rassau, Penasu and Bawang Assan (excludes the polling station of SJK Boi Ing Lebaan 1). Those classified as rural Chinese areas include SJK Boi Ing Lebaan 1 and polling districts of Kunyit, Ma'aw, Selalo, Dassan, Ensurai, Lan and Engkilo. The polling districts of Lower island, Upper Island and Tanah Mas are considered Urban Chinese areas.

${ }_{* *}$ Total votes received by the respective candidates includes the postal votes which are not displayed. The total votes received in 2011 election by all candidates were 12,824, in 2016 were 14,631. 
Chiew made a small gain of 136 votes among rural Iban voters when compared with the 2011 DAP performance, though it represented a much-reduced proportion of the total votes cast in the area. The drop in the absolute number of votes for DAP among the urban Chinese was more significant, possibly due to the abstention of staunch supporters of DAP, who grudgingly agreed with Adenan's policies but did not want to vote for BN or Wong.

Yeu and Wong Sing Wei of STAR who campaigned on the platform of "Sarawak for Sarawakians" only obtained a total of 163 votes. They and Bangau lost their deposits. The nightly events organised by STAR, usually a simple stage on the street facing popular coffee shops, received a moderate reception of crowd, who appeared to be curious and attentive to what the candidates had to say. The extremely low level of ballot support they received is an indication that while the voters were not indifferent to this issue, the concern for Sarawak's rights might have been channelled into the hope that Adenan would be in a better position to deliver than the opposition.

The electoral results reflected a clear surge in support for Wong Soon Koh among rural Chinese and Iban voters. Wong attributed his electoral success to the "feel-good factor" and the personal popularity of Adenan. He was particularly pleased with the fact that "for the first time, I got the majority support from the Chinese community" (Wong 2016).

\section{Electoral Results for Dudong}

In the Dudong constituency, Tiong Thai King managed to avenge his defeat by the incumbent Yap Hoi Liong in 2011. Tiong obtained 9,700 votes against Yap's 7,554 , winning with a majority of 2,146 votes. The turnout rate was $72.8 \%$, $1 \%$ down from the 2011 election despite an increase in the total votes cast.

Yap's share of rural Iban votes plunged drastically from 32.7\% in his 2011 contest to a mere $9.3 \%$ or fewer than 500 votes (see Table 3 ). He only maintained a majority vote share $(59.4 \%)$ in the urban Chinese area, where hard core DAP supporters resided, but this was significantly lower than his 2011 high of $67.2 \%$. His support in the mixed township area of Sibu Jaya and Usaha Jaya with a large Iban population was down by more than half, while shedding a third of votes in the ethnically mixed outskirt area dominated by the Chinese population.

Like Wong in Bawang Assan, Tiong won a plurality of support in all areas except among the urban Chinese voters. Even for the latter, his share of votes among the urban Chinese improved from $28 \%$ to $37 \%$, with a notable increase of 
more than 1,000 votes. Tiong's share of votes improved in all areas (though not always in absolute number), except among rural Iban voters (decreasing from $66.1 \%$ to $45.3 \%$ ) due to Benny Lee.

The candidate who sprang a surprise was Benny Lee, who put up a strong showing in the rural Iban area. He managed to obtain 2,250 votes there, which was $42.3 \%$ of the rural Iban support. That was quite a feat against Tiong, who obtained 2,410 votes or $45.3 \%$ of the rural Iban votes. Unfortunately for Lee, he only received less than $3 \%$ of the urban Chinese votes, and less than $20 \%$ of votes in ethnically mixed rural and urban areas.

Table 3: Micro-analysis of voting pattern in Dudong constituency*

\begin{tabular}{|c|c|c|c|c|c|c|c|c|c|c|}
\hline \multirow{3}{*}{$\begin{array}{l}\text { Candidate } \\
\text { Year } \\
\text { Voters' profile }\end{array}$} & \multicolumn{4}{|c|}{ Tiong Thai King } & \multicolumn{4}{|c|}{ Yap Hoi Liong } & \multirow{2}{*}{\multicolumn{2}{|c|}{$\begin{array}{c}\text { Benny Lee } \\
2016\end{array}$}} \\
\hline & \multicolumn{2}{|c|}{2011} & \multicolumn{2}{|c|}{2016} & \multicolumn{2}{|c|}{2011} & \multicolumn{2}{|c|}{2016} & & \\
\hline & Votes & $\%$ & Votes & $\%$ & Votes & $\%$ & Votes & $\%$ & Votes & $\%$ \\
\hline Rural Iban areas & 3,063 & 66.1 & 2,410 & 45.3 & 1,517 & 32.7 & 497 & 9.3 & 2,250 & 42.3 \\
\hline $\begin{array}{l}\text { Rural Chinese } \\
\text { and Iban areas }\end{array}$ & 1,023 & 44.2 & 1,187 & 46.9 & 1,274 & 55.0 & 878 & 34.7 & 439 & 17.3 \\
\hline $\begin{array}{l}\text { Urban Chinese } \\
\text { areas }\end{array}$ & 2,425 & 28.0 & 3,567 & 37.0 & 5,813 & 67.2 & 5,728 & 59.4 & 248 & 2.6 \\
\hline $\begin{array}{l}\text { Urban Iban and } \\
\text { Chinese areas }\end{array}$ & 2,125 & 66.3 & 1,766 & 67.9 & 1,013 & 31.6 & 439 & 16.9 & 334 & 12.8 \\
\hline Total votes ${ }^{* *}$ & 9,332 & 48.7 & 9,700 & 46.4 & 9,649 & 50.4 & 7,554 & 36.1 & 3,288 & 15.7 \\
\hline
\end{tabular}

Notes: " Rural Iban areas include the polling districts of Naman, Menyan, all except one polling station in Assan, two polling stations in Pak and one in Sibu Jaya. Rural Chinese and Iban areas include selected polling stations in Assan, Pak and Dudong. Urban Chinese areas include the polling districts of Salim, Lanang, Aik Dee, Lada and Mantis. Urban Iban and Chinese areas include some polling stations in Sibu Jaya and Usaha Jaya.

** Total votes received by the respective candidates includes the postal votes which are not displayed. Total votes received in 2011 election by all candidates were 19,155 , in 2016 were 20,922 .

According to Oliver Kuo, the electoral agent of Tiong, local SUPP leadership was against Lee's initiative to contest as an independent, as they were betting on Yap to defeat Tiong. Hence SUPP members were asked to vote for Yap instead of Lee, which translated into low support for Lee among urban Chinese voters. In fact, the SUPP Dudong branch published a statement in See Hua Daily News on the eve of voting day, categorically stating that the Dudong branch strongly opposed "any independent candidate, or expelled former SUPP member, or candidate with tycoon background." It also specified that Chieng Buong Toon, who was contesting the Bukit Assek seat, was the only SUPP candidate. Read literally, it was a statement urging (Chinese) voters to support Chieng, but none of the contestants of Bukit Assek fell into any of the three categories it urged to reject. It was clearly an indirect message urging 
SUPP supporters to reject Tiong (tycoon) and Lee (expelled ex-SUPP member contesting as an independent) and vote for Yap.

Several informants attributed the loss of support for DAP to the personality of Yap. They described Yap as arrogant or not very approachable. Many were allegedly disappointed with his performance as an assemblyman. Even though he is familiar with the Iban culture and speaks fluent Iban, rural Iban voters were unhappy that he could not deliver in terms of the servicing or upgrade of rural infrastructure and public amenities needed by them.

Would Yap have done better in Dudong if Lee did not contest? It is rather doubtful as Lee's platform shared more similarities with Tiong than Yap. Lee had been building rapport with the Iban constituencies for more than a year on the basis that, contrary to Yap, he would be able to mobilise resources to service the rural infrastructure, SUPP being a component party of the ruling BN. He had also proven that he could deliver his promises through the Rural Transformation Funds. Even though he eventually had to contest as an independent, he constantly stressed that he would go back to SUPP should he win the election. Following this logic, his supporters would have supported Tiong should he decide not to contest. On the other hand, in view of the substantial amount of Iban votes obtained by Benny Lee, it is not inconceivable that if he were nominated as a BN candidate to contest the Dudong seat, he would have won the seat with an even greater majority than Tiong. The effectiveness of this mode of rallying support remains potent among rural voters due to their socio-economic profile.

\section{CONCLUSION}

The popularity of Adenan's policy orientation did appear to have a substantial impact on the Chinese electorate. A diachronic analysis of the evolution in voting patterns by polling districts between the 2011 and 2016 state elections suggests similarities in the voting trends for both constituencies. It also provides a more nuanced understanding of the purported "increase" in Chinese support, indicating an urban-rural contrast.

Despite experiencing a drop in the absolute number of votes received, DAP in both cases maintained their majority support among the urban Chinese, where hardcore DAP supporters reside. A drop in the turnout rate unique to the urban Chinese areas may also be interpreted as a possible gesture of abstention in favour of $\mathrm{BN}$. Chinese voters residing in localities further away from the centre of 
Sibu town nonetheless indicated a clear surge in their support for BN, both in absolute number and vote share, hence contributing decisively to the victories of Tiong and Wong. In effect, Wong was quite pleased to publicise the fact that he unprecedentedly won the popular vote in the Chinese majority areas, rural and urban combined. The BN candidates also received solid support from among rural Iban voters, but their respective gains were partially affected by independent candidates who diverted their support from the former. This pattern of comparative strength of rural and urban Chinese support for BN versus DAP candidates corresponds with the findings of Ngu (2017) in her study of the electoral dynamics in Repok and Meradong, who found that the reduced voting rate of urban Chinese benefited SUPP candidates while rural Chinese support for the latter experienced a surge.

The "Adenan effect" may be credited to the success of Adenan in taking full advantage of his position as the sitting Chief Minister to set the political agenda and lead in political narrative. He anticipated and dealt with legacy issues and emerging ones in a proactive way. Reclaiming the rights and autonomy of Sarawak, as we noted, was a favourite theme among several candidates. Adenan acknowledged this groundswell of regional nationalism early on and harnessed the sentiment to his advantage by asking for a stronger mandate to negotiate with Putrajaya. His astute crafting of an inclusive political narrative for and as Sarawakians took the wind out of the sails of DAP's electoral campaign, as the federal excesses of Malay ethno-nationalist discourse and Islamisation policies had been one of the popular themes which resonated with the Chinese voters in Sarawak. Issues such as $1 \mathrm{MDB}$ scandal, tycoon money politics and GST also appeared not to have brought more support for DAP, except among a section of the urban Chinese. This was notwithstanding the fact that the strong anti-corruption rhetoric Adenan adopted in order to project an image of a clean reformist was betrayed by his nomination of five Chinese business tycoons or their family members as BN candidates.

Taking Dudong and Bawang Assan constituencies as the focus of localised study provides insights into the intricate political dynamics on the ground, and the way in which the "Adenan effect" was tapped by the BN candidates during the campaign to rally support. A closer zoom into local politics reveals that rivalry and political manoeuvring were rife even among $\mathrm{BN}$ candidates and component parties. The value of intensive local immersion and investigation to understand electoral politics is to go behind the "Adenan effect" to understand how local social actors interacted and how the various local factors also came into play in doing politics. 


\section{ACKNOWLEDGEMENTS}

This research was funded by Universiti Kebangsaan Malaysia research fund, Dana Penyelidikan Top Down in a research project entitled "Personalized Politics, Provincialism and Prices: Issues and Voting Determinants in the 2016 Sarawak State Elections" (Grant number: TD-2016-002). My grateful appreciation is due to Huong Haw Ching and Clarence Ting for kindly providing me with the information on the respective electoral results and analyses of the two electoral constituencies.

\section{REFERENCES}

Banji, C. 2016. Assessment rate reductions revealed. Borneo Post Online, 28 April. http://www.theborneopost.com/2016/04/28/assessment-rate-reductions-revealed/ (accessed 30 June 2017).

Boon, P. 2016. Newcomer Mary Ting fielded by STAR for Dudong. Borneo Post Online, 17 April. http://www.theborneopost.com/2016/04/17/newcomer-mary -ting-fielded-by-star-for-dudong/ (accessed 28 June 2017).

Bernama. 2016. SUPP to contest 21 seats at S'wak polls. 8 February. https://www .malaysiakini.com/news/329811 (accessed 7 July 2017).

Borneo Post Online. 2015a. S4S supporters raise bail for Yeu. 7 August. http://www .theborneopost.com/2015/08/07/s4s-supporters-raise-bail-for-yeu/_ (accessed 28 June 2017).

2015b. S4S against any secession move, assures Peter. 3 November. http://www.theborneopost.com/2015/11/03/s4s-against-any-secession-move -assures-peter/ (accessed 28 June 2017).

2016. Ex-broadcaster hopes to stand as BN-friendly candidate in Dudong.

2 April. http://www.theborneopost.com/2016/04/02/ex-broadcaster-hopes-to -stand-as-bn-friendly-candidate-in-dudong/ (accessed 30 June 2017).

Borneo Post. 2016. Watson's candidacy surprises, disappoints Wong. 26 April, page 2.

Cheng, L. 2016. Yeu to lose Bawang Assan candidacy if convicted. Borneo Post Online, 4 May. http://www.theborneopost.com/2016/05/04/yeu-to-lose-bawang-assan -candidacy-if-convicted-in-court/ (accessed 28 June 2017).

Chie, K.G. 2016. Sabotage threatens BN's big win plan. Malaysiakini, 27 April. https://www.malaysiakini.com/news/339374 (accessed 18 April 2021).

Chin, J. 1996. The Sarawak Chinese voters and their support for the Democratic Action Party (DAP). Southeast Asian Studies 34(2): 387-401. https://doi.org/10.20495/ tak.34.2_387

2012. Forced to the periphery: Recent Chinese politics in East Malaysia. In Malaysian Chinese: Recent developments and prospects, eds. H.G. Lee and L. Suryadinata, 109-124. Singapore: Institute of Southeast Asian Studies. 
2015. The 'Pek Moh' factor and the Sarawak parliamentary seats. In Coalitions in collision: Malaysia's $13^{\text {th }}$ general elections, eds. J. Saravanamuttu, H.G. Lee and Mohamed Nawab Mohamed Osman, 181-198. Petaling Jaya: Strategic Information and Research Development Centre; Singapore: Institute of Southeast Asian Studies.

Chin, U.H. 1997. Chinese politics in Sarawak: A study of the Sarawak United People's Party. Kuala Lumpur: Oxford University Press.

Chua, A. 2018. Sarawak for Sarawakians organiser acquitted. The Star, 15 January. https://www.thestar.com.my/news/nation/2018/01/15/sarawak-for-sarawakiansorganiser-acquitted/ (accessed 18 April 2021).

Faisal S. Hazis. 2011. Making sense of the 2011 Sarawak state elections. Aliran Monthly Online, 14 April. https://aliran.com/web-specials/2011-web-specials/making -sense-of-the-sarawak-state-elections/ (accessed 16 June 2017).

Liew, J.T. 2017. Sarawak's longstanding business rivalry. The Edge Malaysia, 4 May. https://www.theedgemarkets.com/article/cover-story-sarawaks-long-standing -business-rivalry (accessed 17 April 2021).

Malaysiakini. 2014. Don't mess with me, CM warns timber tycoons. 17 November. http://www.malaysiakini.com/news/280773 (accessed 30 June 2017).

. 2016a. Adenan: Sarawak civil service posts open to UEC holders. 9 March. https://www.malaysiakini.com/news/333450 (accessed 9 March 2016).

. 2016b. Adenan's approval at record high but stronger opposition wanted. 19 April. http://www.malaysiakini.com/news/338411 (accessed 29 June 2017).

Ngu, I.T. 2014. Sibu and Lanang, Sarawak: Defeat of the bosses. In Electoral dynamics in Malaysia: Findings from the grassroots, ed. M.L. Weiss, 235-249. Petaling Jaya: Strategic Information and Research Development Centre; Singapore: Institute of Southeast Asian Studies.

2017. Repok and Meradong: Challenges in courting rural votes. In Electoral dynamics in Sarawak: Contesting developmentalism and rights, eds. M.L. Weiss and A. Puyok, 67-96. Singapore: ISEAS-Yusof Ishak Institute.

See Hua Daily News. 2016. 27 April, page 7.

Tan, J. 2016. Adenan's Chinese courtship. The Star, 20 March. http:/www.thestar.com .my/opinion/columnists/analysis/2016/03/20/adenans-chinese-courtship/ (accessed 15 June 2017).

Tawie, S. 2015. Islam no more official religion on Sarawak government website. The Malay Mail Online, 11 December. http://www.themalaymailonline.com/ malaysia/article/islam-no-more-official-religion-on-sarawak-government -website (accessed 12 December 2015).

The Malaysian Insider. 2015a. Sarawak CM warns ministers, assistant ministers against corrupt practices. 15 January. http://www.themalaysianinsider.com/malaysia/ article/sarawak-cm-warns-ministers-assistant-ministers-against-corrupt-practices (accessed 15 January 2015).

2015b. Sarawak passes motion to safeguard rights under Malaysia agreement. 8 December. http://www.themalaysianinsider.com/malaysia/article/ sarawak-passes-motion-to-safeguard-rights-under-malaysia-agreement (accessed 8 December 2015). 
United Daily News. 2016. 26 April, page A14.

Utusan Borneo Online. 2016. Kayong minta pengundi Iban sokong beliau. 4 May. https://www.utusanborneo.com.my/2016/05/04/kayong-minta-pengundi-iban -sokong-beliau (accessed 18 April 2021).

Wong, P. 2016. Soon Koh attributed victory to Adenan's feel-good factor. Borneo Post Online, 8 May. http://www.theborneopost.com/2016/05/08/soon-koh-attributes -victory-to-adenans-feel-good-factor/ (accessed 14 June 2017). 